\title{
Influence of Classroom Learning Modus, Locus of Control Type, Learning Ethos, Characteristic of Profession Practice Place, Capability and Mindset Entrepreneurship Graduate of Polytechnic of Road Transport Safety
}

\author{
$1^{\text {st }}$ Suyitno \\ Departement of Civil \\ Engineering, \\ Faculty of Engineering, \\ Universitas Negeri Malang, \\ Jawa Timur, Indonesia \\ suyitnoalekalek@yahoo.co.id
}

\author{
$2^{\text {nd }}$ Amat Mukhadis \\ Departement of Machine \\ Engineering, \\ Faculty of Engineering, \\ Universitas Negeri Malang, \\ Jawa Timur, Indonesia \\ mukhadis_s@yahoo.com
}

\author{
$3^{\text {rd }}$ Sy arif Suhartadi \\ Departement of Machine \\ Engineering, \\ Faculty of Engineering, \\ Universitas Negeri Malang, \\ Jawa Timur, Indonesia \\ Syarif57@gmail.com
}

\author{
$4^{\text {th }}$ Eddy Sutadji \\ Departement of Machine \\ Engineering, \\ Faculty of Engineering, \\ Universitas Negeri Malang, \\ Jawa Timur, Indonesia \\ eddysutadji@gmail.com
}

Abstract - The objectives of the study were to find, construct new theories: (1) direct influence of classroom learning modes on graduates' capabilities, (2) direct influence of control locus types on graduate capability, (3) direct influence of learning ethos on graduate capability, (4) direct influence (5) direct influence of the locus type of control on the entrepreneurship mindset of graduates, (7) the direct influence of the learning ethos on the entrepreneurship mindset of graduates, (8) the influence of direct learning mode on the entrepreneurship mindset of graduates, (9) direct influence of graduate capability to entrepreneurship mindset graduates and (10) direct influence between graduate capability with entrepreneurship mindset to learning mode, type of locus of control, study ethos and characteristics of professional work place . This research uses SEM (Structural Equation Modeling) analysis with AMOS program.

The subject of this research is all cadets of PKTJ. Data collected through questionnaires were tested using validity and intrument reliability test. The results of the research indicate that: (1) there is a direct and significant influence of the classroom learning mode on the graduates' capability, (2) there is a direct and significant influence of the locus type of control on the graduate capability; (3) there is a direct and significant influence of the learning ethos on the graduate capability, (5) there is a direct and significant influence of the mode of learning on the entrepreneurship mindset of graduates, (6) there is a direct and significant influence of the type of locus of control on the entrepreneurship mindset of graduates, (7) ) there is a direct and significant influence of the learning ethos on the entrepreneurship mindset of graduates, (8) there is a direct and significant influence on the characteristics of professional workplace practices on the entrepreneurship mindset of graduates; (9) there is a direct and significant influence of the graduate's capability to the graduate entrepreneurship mindset and (10) direct and significant influence between graduate capability with the mindset of entrepreneurship to the mode of learning, the type of locus of control, the learning ethos and the characteristic of the professional workplace.
Keywords - Learning Modes, Locus of Control, Learning Ethos, Professional Practice, Capabilities, Mindset Entrepreneurship.

\section{INTRODUCTION}

The issue of ready-to-use employment with employment needs remains a crucial issue in Indonesia. The absence of manpower occurs due to various factors, one of which is the incompatibility factor of graduate competence of educational institutions with a job on existing jobs on existing labor users, in order to compete to obtain employment required competent and competent human resources high. This is a serious problem that needs to be taken into consideration especially in education.

Based on a survey of the national labor force of the Central Bureau of Statistics found data that the number of open unemployment in Indonesia until August 2014 reached $7,244,905$ people. Of the number of unemployed are educated Diploma I, II, III / Academy 193,517 people or 3\%.

The perspective of cadets of PKTJ is related to his desire to work after graduation, namely to become a Civil Servant within the Ministry of Transportation, the condition becomes the hope of every graduate who intends to devote himself to the nation and state through a position as a regulator in the government. The fact that not all graduates can be accommodated to civil servants within the Ministry of Transportation because of limited formation and tight selection by the government. This proves that many factors influence the capability and mindset of entrepreneurship graduates so that the low ability of the PKTJ graduates to be accepted in public servants.

It is therefore necessary to conduct research on the effect of classroom learning mode, type of locus of control, learning ethos, characteristics of the professional workplace 
on capability and mondset entrepreneurship graduated from the Polytechnic of Road Transport Safety. So that will be obtained a recommendation of the model graduates in accordance with the needs of the world of work. Taruna that passpun can apply in the world of work.

\section{LEARNING MODUS}

It is the way, the process, how things work, while learning is a relatively permanent change in behavior or potential behavior as a result of reinforced experience or practice [3]. Learning Mode Introduced Jerome S. Bruner Learning in the view of bruner is an active process in finding new things beyond the information given to him. Children are regarded as human beings thinkers and creators of information.

This definition leads us to the understanding that there are ways that can be used in school activities. The word 'learning' in the context of learning means (1) seeking to gain intelligence or knowledge, and (2) changing behavior or responses caused by experience.

\section{LOCUS OF CONTROL TYPE}

Locus of Control or control locus which is the individual psychological control of their work and their belief in self-efficacy. The focus of this control is divided into two: the internal control locus that characterizes a person having confidence that they are responsible for their work behavior in the organization. The focus of external control that characterizes the individual who believes that the work behavior and the success of their task are more due to factors outside the organization [5].

\section{LEARNING ETHOS}

The learning ethos can be defined as the evaluative aspect as a fundamental attitude toward themselves and their world that is reflected in their lives to gain new experiences [6]. The index of the learning ethos is concerned with the evaluation aspects of learning and the measurement of a learning outcome.

\section{CHARACTERISTICS OF PROFESSION PRACTICE PLACE}

Characteristics of place of Professional Practice is a learning activity activity for cadets in the workplace actually as a form of relevance between the accepted theories on campus with the practices encountered in the world of work, with the characteristics of specificity in the field of road transport safety technical experts, work materials, tools used, technical expertise as a way, service users and operational costs [2].

\section{CAPABILITY}

The capability is the ability to exploit both the resources possessed within and within the organization, as well as the potential of self to perform certain activities or a series of activities [1].

\section{MINDSET ENTREPRENEURSHIP}

It is the mindset of a person to understand the importance of ability in terms of creating business activities or something new. Creating ability requires constant creativity and innovation to find something that is different from pre-existing ones, where there are several accompanying aspects such as psychic, social, financial and other risks [4].

\section{RESEARCH METHODS}

THE population in this research is cadet Polytechnic of Road Transport Safety with a sample of 230 cadets. This research is quantitative research with survey model, post positivistic. The data collection method uses questionnaires to collect data from cadets in the form of learning, locus type control, ethos or learning attitudes, practice characteristics, capabilities and mindset of entrepreneurship graduates. Data analysis technique used in this research is SEM (Structural Equation Modeling) analysis using AMOS program version 22.0. This analysis provides a model of the direct and indirect influence of learning mode variables, type of locus of control, ethos or learning attitudes, practice characteristics, capabilities and mindset of entrepreneurship.

\section{RESULT AND DISCUSSION}

The population in this research is cadet Polytechnic of Road Transport Safety with a sample of 230 cadets. This research is quantitative research with survey model, post positivistic. The data collection method uses questionnaires to collect data from cadets in the form of learning, locus type control, ethos or learning attitudes, practice characteristics, capabilities and mindset of entrepreneurship graduates.

Data analysis technique used in this research is SEM (Structural Equation Modeling) analysis using AMOS program version 22.0. This analysis provides a model of direct and indirect influence of learning modes variables, type of locus of control, ethos or learning attitudes, practice characteristics, capabilities and mindset of entrepreneurship

\section{A. Effect of Learning Modes on Capability}

H1. There is a direct and significant influence on the classroom learning mode on the graduate capability of the Polytechnic of Road Transport Safety. The estimation parameter of the relationship between both variables was obtained at 1.536 . The test showed significant results with a qualified $\mathrm{CR}=2.252>1.96$ with probability $=0.024$ that qualified test probabilities were below 0.05 . Thus $\mathrm{H} 1$ in this study is acceptable.

\section{B. Influence of Control Type on Capability}

$\mathrm{H} 2$. There is a direct and significant influence on the type of locus of control on the graduate capability of the Polytechnic of Road Transport Safety. Parameter estimation relation of both variables is obtained equal to 0,331 . Tests showed insignificant results with unbalanced $\mathrm{CR}=1.287>1.96$ with probability $=0.198$ which did not meet the probability test requirement to be above 0.05 . Thus $\mathrm{H} 2$ in this study is unacceptable.

\section{Effect of Learning Ethos on Graduate Capability}

H3. There is a direct and significant influence between the learning ethos on the graduate capability of the 
Polytechnic of Road Transport Safety. The estimation parameter of the relationship of both variables is obtained equal to -2,849. Testing showed significant results with a value of $\mathrm{CR}=-1.96$ eligible> 1.96 with probability $=0.049$ that qualified test probabilities were below 0.05 . Thus $\mathrm{H} 3$ in this study is acceptable.

D. Influence of Characteristics of Professional Practice Place on graduate capability.

H4. There is a direct and significant influence on the characteristics of the place Practice professional work on the capabilities of PKTJ graduates.

The estimation parameter of the relationship between these two variables was obtained for 2.183. The test showed significant results with the value of $\mathrm{CR}=2.767$ who qualified $>1.96$ with probability $=0.006$ which qualified test probability was below 0.05 . Thus $\mathrm{H} 4$ in this study is acceptable.

E. The influence of the classroom learning mode on the entrepreneurship graduate of the graduate.

H5. There is a direct and significant influence on the classroom learning mode on the entrepreneurship mindset Graduate of the Polytechnic of Road Transport Safety.

The parameter estimates the relationship between these two variables obtained by 1.373 . The test showed significant results with a qualified $\mathrm{CR}=4.488>1.96$ with probability $=0.013$ that qualified test probabilities were below 0.05 . Thus H5 in this study is acceptable.

\section{$F$. Influence The locus type of control on the} entrepreneurship mindset graduates.

H6. There is a direct and significant influence on the type of locus of control on the entrepreneurship mindset graduated from the Polytechnic of Road Transport Safety.

Parameter estimation of the relationship between these two variables obtained for 0.341. Tests showed insignificant results with unobtainable $\mathrm{CR}=1.601$ > 1.96 with probability $=0.109$ which did not meet the probability test requirement to be above 0.05 . Thus H6 in this study is unacceptable.

G. The influence of the learning ethos on the mindset of entrepreneurship graduates

.H7. There is a direct and significant influence between the learning ethos of the entrepreneurship mindset graduated from the Polytechnic of Road Transport Safety.

Parameter estimation relation of both variables is obtained equal to -2.298 . Tests showed significant results with a value of $\mathrm{CR}=-1.983$ eligible> 1.96 with probability $=0.047$ that qualified test probabilities were below 0.05 . Thus $\mathrm{H7}$ in this study is acceptable
H. The influence of practice profession work place characterictic on the mindset of entrepreneurship graduates

The influence of PKP place characteristics on the entrepreneurship mindset of graduates. H8. There is a direct and significant influence on the characteristics of professional work practice significant to the entrepreneurship mindset graduated from the Polytechnic of Road Transport Safety.

The estimation parameter of the relationship between both variables was obtained at 1.321. Testing showed significant results with a value of $\mathrm{CR}=2.291$ eligible 1.96 with probability $=0.022$ which qualifies test probabilities to be below 0.05 . Thus $\mathrm{H} 8$ in this study is acceptable.

I. Influence Capability to the entrepreneurship mindset of graduates

H9. There is a direct and significant influence between the graduate capability to entrepreneurship mindset graduated from Polytechnic of Road Transport Safety. Parameter estimation relation of both variables is obtained equal to 0,730 . The test showed significant results with the value of $\mathrm{CR}=7,362$ eligible> 1.96 with probability $=0,000$ which qualifies the probability testing to be below 0.05 . Thus H9 in this study is acceptable.

J. Effect of classroom learning mode, type of locus kendai, learning ethos, PKP place characteristics to the capability and mindset of entrepreneurship graduates.

H10. There is a direct and significant influence on the classroom learning mode, the type of locus of control, the learning ethos and the characteristics of the professional workplace on the graduate capability and mindset of entrepreneurship graduated from the Polytechnic of Road Transport Safety.

Parameter estimation relation of both variables is obtained equal to 0,730 . The test showed significant results with the value of $\mathrm{CR}=7,362$ eligible> 1.96 with probability $=0,000$ which qualifies the probability testing to be below 0.05 . Thus $\mathrm{H} 10$ in this study is acceptable.

\section{CONCLUSION}

Firstly, there is a direct and significant influence on the classroom learning mode on the graduate capability of the Polytechnic of Road Transport Safety. That is, the better the classroom learning mode, the better the graduate of Polytechnic of Road Transport Safety. Second, there is a direct and significant influence on the type of locus of control on the graduate capability of the Polytechnic of Road Transport Safety. That is, the better the type of locus of control, the better the graduate of Polytechnic of Road Transport Safety. Third, there is a direct and significant influence between the learning ethos on the graduate capability of the Polytechnic of Road Transport Safety. This 
means that the better the learning ethic, the better the graduate of Polytechnic of Road Transport Safety.

Fourthly, there is a direct and significant influence between the characteristics of the professional workplace on the graduation capability of the Polytechnic of Road Transport Safety. That is, the better the characteristics of professional work practices will be the better capability of graduates of Polytechnic of Road Transport Safety.

. Fifthly, there is a direct and significant influence between the classroom learning mode on the entrepreneurship mindset graduated from the Polytechnic of Road Transport Safety. That is, the better the classroom learning mode the better the mindset of entrepreneurship graduated from the Polytechnic of Road Transport Safety.

Sixth, there is a direct and significant influence between the type of locus of control on the mindset of entrepreneurship graduated from the Polytechnic of Road Transport Safety. That is, the better the type of locus of control will be the better mindset entrepreneurship graduate Polytechnic of Road Transport Safety.

Seventh, there is a direct and significant influence between the learning ethos of the entrepreneurship mindset graduated from the Polytechnic of Road Transport Safety. That is, the better the learning ethic will be the better Mindset Entrepreneurship graduate Polytechnic of Road Transport Safety.

Eighth, there is a direct and significant influence on the characteristics of the workplace profession significant to the entrepreneurship mindset graduated from the Polytechnic of Road Transport Safety. That is, the better the characteristics of the place of professional work practice will be the better mindset entrepreneurship graduate Polytechnic Road Transport Safety.

Ninth, there is a direct and significant influence between the graduate capability to Mindset Entrepreneurship graduate of Polytechnic of Road Transport Safety. It means, the better the graduate capability, the better Mindset Entrepreneurship graduated from Polytechnic of Road Transport Safety.

Tenth, there is a direct and significant influence on the classroom learning mode, the type of locus of control, the learning ethos and the characteristics of the professional workplace on the graduate capability and mindset of entrepreneurship graduated from the Polytechnic of Road Transport Safety. This means that the better the classroom learning mode, the control locus type, the study ethos and the characteristics of the professional workplace will improve the graduate's capability of the Polytechnic of Road Transport Safety and have an impact on the better ndset entrepreneurship graduated from the Polytechnic of Road Transport Safety.

\section{ACKNOWLEDGEMENTS}

I would like to thank the Graduate Program of Post Graduate Education of Malang State University (UM), Faculty of Engineering, State University of
Malang (UM), and Tegal Transportation Safety Polytechnic, for technical support in organizing this seminar.

\section{REFFERENCES}

[1] Amir, M. Taufik, 2011. Manajemen Strategi Konsen \& Aplikasi, PT. Raja Grafindo Persada : Jakarta.

[2] Manajemen Pendidikan (online)

[3] http://www.rumahafid.com.

[4] Diakses pada tanggal 31 Oktober 2013.

[5] Mulyati, Psikologi Belajar, Yogyakarta, CV. Andi Ofsett, 2005.

[6] Robbert D Hisrich, Michael P.Peters. Mc Braw-Hil Higer Education, 2002, Cornel University.

[7] Robbins Stephen P, 2007, Manajemen, Jakarta : PT. Indeks.

[8] Wahyono Kurnianggoro, L., Seo, D.-W., Jo, K.-H : Visual Perception of Traffic sign for an autonomous vehicle using K. nearest cluster neighbour classifier.In: Proceeding of URAI (2014). 